\title{
COMPUTATIONS OF THE POSSIBLE FUTURE BEHAVIOUR OF BERENDON GLACIER, CANADA
}

\author{
By N. UnTERSTEINER \\ (Department of Atmospheric Sciences, University of Washington, Seattle, Washington 98105, \\ U.S.A.) \\ and J. F. NyE \\ (H. H. Wills Physics Laboratory, University of Bristol, Bristol, England)
}

\begin{abstract}
If the surface of Berendon Glacier, British Columbia, Canada, rose by $19 \mathrm{~m}$ above its 1963 level at a certain point near the terminus it would reach the entrance to a mining tunnel. Computations are made to see whether this is likely in the near future.

We calculate the changes in mass balance that would be necessary to make the glacier, which is now retreating, start to advance and reach the tunnel in 40 years and 20 years respectively. The method fits polynomials to the advance-retreat data and then uses the $\lambda$ coefficients of Nye ( $1963[\mathrm{~b}])$ to infer the corresponding mass balance behaviour. It is concluded that if the mean mass balance should increase smoothly to $+70 \mathrm{~cm} /$ year, which is a high but possible value, by the year 2003 , the ice would reach the tunnel portal in 2003 . But, even assuming a rather drastic deterioration in the climate in the future and a concomitant increase of the mean mass balance, the ice will not reach the tunnel portal within the next 20 years.
\end{abstract}

RÉsumé. Computations du comportement futur possible du Glacier Berendon, Canada. Si la surface du Glacier Berendon, Colombie Britannique, Canada, s'élève de $19 \mathrm{~m}$ au-dessus de son niveau de 1963 , a un certain point près de son front, elle atteindrait l'entrée d'un tunnel de mine. Des computations ont été faites pour voir si cela est possible dans un futur proche.

Nous avons calculé les variations du bilan de masse nécessaires pour que le glacier, actuellement en retraît, commence une avance pour atteindre le tunnel en 40 et 20 années respectivement. La méthode met les données d'avance et de retraît en polynomes et utilise alors les coefficients $\lambda$ de Nye (1963[b]) pour en déduire la comportement correspondant du bilan de masse. On en conclut que si le bilan de masse moyen augmentait doucement jusqu'à $+70 \mathrm{~cm} / \mathrm{an}$, ce qui est une valeur forte mais possible, vers l'an 2003, la glace atteindrait l'entrée du tunnel en l'an 2003. Mais, même en supposant une détérioration du climat plutôt catastrophique dans le future, la glace n'atteindrait pas l'entrée du tunnel durant les prochaines 20 années.

Zusammenfassung. Berechnung des möglichen zukünftigen Verhaltens des Berendon-Gletschers. Würde sich der Berendon-Gletscher (British Columbia, Canada) an einer bestimmten Stelle nahe dem Terminus um $19 \mathrm{~m}$ über den Stand von 1963 erhöhen, so würde er den Eingang zu einem Bergwerksstollen erreichen. Die folgenden Überlegungen sollen zeigen, wie wahrscheinlich es ist, dass dies in naher Zukunft eintreten kann.

Wir berechnen die Änderungen des Massenhaushaltes, die notwendig sind, um ein Anschwellen des Gletschers, der sich gegenwärtig im Rückgang befindet, bis zum Stolleneingang in 40 bzw. 20 Jahren zu verursachen. Die Methode besteht darin, die Rückgangs- und Vorstossdaten in Polynomen darzustellen und dann mit Hilfe der $\lambda$-Koeffizienten (Nye, I963 [b]) auf die erforderlichen Massenhaushaltsänderungen rückzuschliessen. Es wird gezeigt, dass mit einem stetigen Ansteigen des Massenhaushaltes auf den hohen, aber möglichen Wert von $+70 \mathrm{~cm} / \mathrm{Jahr}$ im Jahre 2003 das Eis den Stolleneingang erreichen würde. Selbst unter der Annahme einer drastischen Klimaverschlechterung und gleichzeitigen Zunahme des Massenhaushaltes in der Zukunft wird das Eis in den nächsten 20 Jahren nicht bis zum Stolleneingang anschwellen.

\section{INTRODUGTION}

When engineering works are planned close to a glacier it would be a great help to have a reliable method of predicting the future behaviour of the glacier. No such method at present exists. But it is possible, in certain circumstances, to predict what the glacier response would be to a given variation in its mean mass balance. If plausible limits are then set to the possible future variation in mass balance, corresponding limits may be set to the variations of the glacier. Variations in the length caused by other factors than changes in the mass balance are not covered by this procedure, and therefore glacier surges are outside its scope. The strongest indication that an individual glacier is capable of and has experienced surges is the presence of folded moraines. They are not present on the glacier which is the subject of this paper, and there is no reason to believe that it has surged in the past.

The calculations to be described were done to see whether Berendon Glacier (Fig. I), in the Coast Mountains of British Columbia, Canada, was likely to advance sufficiently in the 


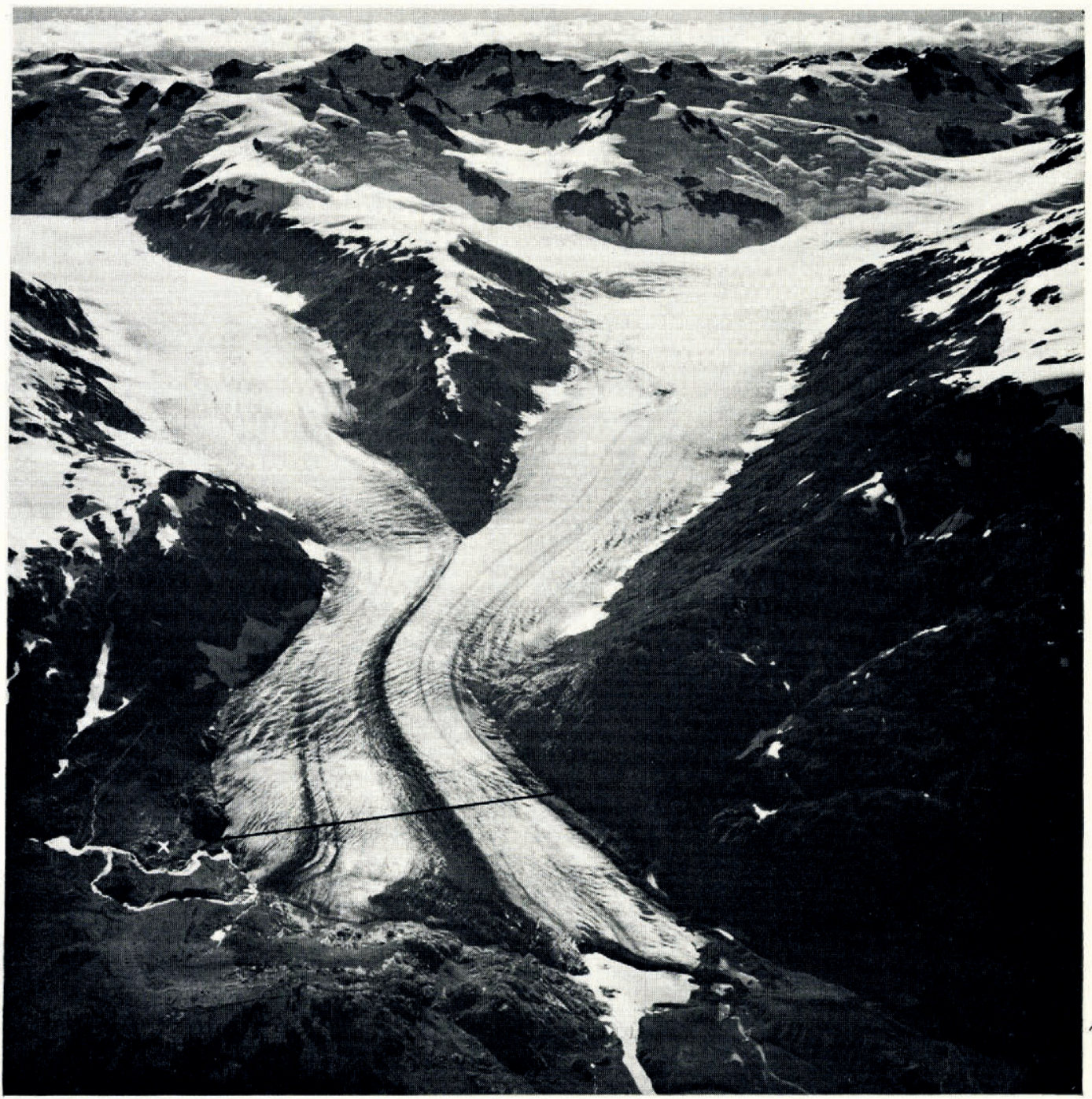

Fig. 1. Berendon Glacier, Coast Mountains of British Columbia, Canada. The tunnel portal, at the point marked X in lower left corner, was $19 \mathrm{~m}$ above and $180 \mathrm{~m}$ horizontally from the edge of the ice in 1963 . Photograph taken by Austin $S$. Post on 8 August 1961

next 40 years or so to be a danger to the mining installations of the Granduc Operating Co.* They are reported here because they illustrate a method that may be useful in similar problems elsewhere. The Berendon Glacier (lat. $56^{\circ}{ }_{1} 5^{\prime}$ N., long. $130^{\circ} 05^{\prime} \mathrm{W}$.), which covers an area of $33 \mathrm{~km}^{2}$ between altitudes of about $2400 \mathrm{~m}$ and $655 \mathrm{~m}$, has two main branches that join

* The Granduc Operating Company (subsidiary of Newmont Mining Corporation) is developing a copper mine situated between the upper end of Bowser River Valley, in the foreground of Figure $\mathrm{I}$, and the Leduc River Valley, which lies in the background to the left of Figure 1 . To reach the deposit, estimated to be 32 million tonnes of ore at 1.9 per cent copper, a tunnel is being drilled (begun in 1964 ) which will eventually be $16 \mathrm{~km} \mathrm{long.} \mathrm{A}$ concentrator of 7000 tonnes per day capacity will be placed near the left-hand bottom corner of Figure $\mathrm{I}$. An estimated 500 tonnes per day of concentrate will be taken by a specially built road which follows the edge of the south tongue of Salmon Glacier to Stewart, B.C., and will be shipped to a smelter at Tacoma, Wash. Production is planned to begin in 1969 . The total investment in these installations is of the order of 100 million dollars. 
together at an altitude of $1100 \mathrm{~m}$. It has not been extensively studied, and in this respect it differs from the other glaciers to which this type of theory has been applied, namely South Cascade Glacier, Washington, U.S.A. and Storglaciären, Kebnekaise, Sweden. The data for these last two glaciers were of high quality and the results of the computations were correspondingly reliable; in contrast, the data used for Berendon Glacier necessarily involved a good deal of guesswork. In spite of this the results are thought to be significant, and certainly better than estimates of the likely behaviour of the glacier based on no theory at all.

\section{Procedure}

The theory used, which is concerned only with changes in the glacier that are small compared with the overall dimensions, is developed in the five papers (Nye, r960, 1963[a], $1963[b], 1965[a], 1965[b])$, of which Nye $\left(1_{963}[b]\right)$ is the most relevant for our present purpose and is more or less self-contained. The glacier is characterized by three functions $B_{0}(x), \mathbf{c}_{o}(x), \mathbf{D}_{0}(x)$, where $x$ is a coordinate denoting distance down the glacier, the functions being respectively the width of the glacier in a datum state, the velocity of kinematic waves multiplied by $B_{0}$, and the diffusivity of kinematic waves multiplied by $B_{0}$. To estimate these functions for the Berendon Glacier we used the same procedure as that already fully described for South Cascade Glacier (Nye, I $963[\mathrm{~b}]$ ) and Storglaciären (Nye, I965[a]), the only difference in this case being the paucity of the observational data.

TABLE I

\begin{tabular}{|c|c|c|c|c|c|c|c|c|c|}
\hline $\begin{array}{c}x \\
\mathrm{~m}\end{array}$ & $\underset{\mathrm{m}}{z}$ & $\begin{array}{l}B_{0} \\
\mathrm{~m}\end{array}$ & $\begin{array}{c}\alpha_{0} \\
\text { deg }\end{array}$ & $\begin{array}{c}S_{0} \times \mathrm{IO}^{-4} \\
\mathrm{~m}^{2}\end{array}$ & $\begin{array}{c}a_{0} \\
\text { m year }{ }^{-1}\end{array}$ & $\begin{array}{r}\mathbf{q}_{0} \times \mathrm{IO}^{-4} \\
\mathrm{~m}^{3} \text { year }^{-1}\end{array}$ & $\begin{array}{l}\mathbf{D}_{0} \times \mathrm{IO}^{-7} \\
\mathrm{~m}^{3} \text { year }^{-1}\end{array}$ & $\begin{array}{c}u_{0} \\
\text { m year }\end{array}$ & $\begin{array}{c}\mathbf{c}_{0} \times \mathrm{IO}^{-4} \\
\mathrm{~m}^{2} \text { year }^{-1}\end{array}$ \\
\hline 0 & & 4000 & 6.2 & o & & o & o & o & o \\
\hline 600 & $\begin{array}{l}\text { I } 830 \\
6-0\end{array}$ & 10000 & 8.0 & $5^{\circ}$ & $\begin{array}{l}2.15 \\
\\
1.65\end{array}$ & $9 \circ 3$ & I9.3 & 18.0 & 72.0 \\
\hline 1200 & & I I 500 & 10.2 & 115 & & $208 \mathrm{I}$ & $34 \cdot 7$ & I8.1 & 83.2 \\
\hline I 800 & 1440 & 8200 & $7 \cdot 4$ & 115 & 0.35 & $25^{8} 3$ & $59 \cdot 6$ & 22.5 & 73.8 \\
\hline 2400 & 1380 & 5700 & 5.6 & 87 & -0.25 & 2729 & 83.5 & $3^{1} \cdot 4$ & 71.6 \\
\hline 3000 & I 320 & 3900 & 6.3 & 62 & -0.85 & 2657 & $72 \cdot 3$ & $4^{2.8}$ & 66.8 \\
\hline 3600 & 1280 & 2700 & $4 \cdot 7$ & 43 & -1.35 & $24^{87}$ & 90.8 & 57.8 & 62.5 \\
\hline 4200 & I 220 & 2100 & 4.8 & $3^{2}$ & -2.05 & 2293 & 81.8 & 71.6 & 60.1 \\
\hline $4^{800}$ & 1170 & 2040 & $5 \cdot 3$ & $29 \cdot 5$ & -2.65 & 2047 & 66.3 & 69.5 & $5^{6.7}$ \\
\hline 5400 & I 110 & I $95^{\circ}$ & 7.2 & 27.8 & -3.25 & I $73 \mathrm{I}$ & $4^{1.1}$ & 62.3 & $4^{8.6}$ \\
\hline 6000 & 1050 & I 520 & 7.0 & 15.9 & -3.95 & I 394 & 34.0 & $87 \cdot 7$ & 53.2 \\
\hline 6600 & 970 & I 240 & 4.6 & ${ }^{1} 5.8$ & -4.85 & I 069 & 39.8 & 67.7 & 33.6 \\
\hline 7200 & 890 & 840 & 6.5 & 10.8 & -5.75 & 767 & 20.2 & 71.0 & 23.8 \\
\hline 7800 & 790 & 800 & 11.0 & $7 \cdot 5$ & -6.75 & 477 & $7 \cdot 35$ & $63 \cdot 5$ & 20.3 \\
\hline 8400 & 710 & 720 & 14.5 & $4 \cdot 7$ & -7.75 & 169 & 1. 96 & 36.0 & 10.4 \\
\hline 8790 & & $39^{\circ}$ & 15.0 & o & & o & 0 & I 8 & 0.7 \\
\hline $\begin{array}{l}\text { distan } \\
\text { heigh } \\
\text { width } \\
\text { slope } \\
\text { area }\end{array}$ & $\begin{array}{l}\text { rom he } \\
\text { surface } \\
\text { glacier } \\
\text { urface } \\
\text { oss-sect }\end{array}$ & $\begin{array}{l}\text { f glacie } \\
\text { ve mear }\end{array}$ & -level & & \multicolumn{5}{|c|}{$\begin{aligned} \mathbf{q}_{0} & =\int_{0} a_{0} B_{0} \mathrm{~d} x=\text { discharge } \\
\mathbf{D}_{0} & =3 \mathbf{q}_{0} \cot \alpha_{0}=\text { diffusion coefficient } \times B_{0} \\
u_{0} & =\mathbf{q}_{0} / S_{0}=\text { ice velocity } \\
\mathbf{c}_{0} & =4 B_{0} u_{0} \text { (except near terminus) = wave velocity } \times E\end{aligned}$} \\
\hline
\end{tabular}

Suffix zero refers to datum-state values 
There are three topographical maps of Berendon Glacier (scale I : I 200, contour interval $20 \mathrm{ft}(6 . \mathrm{I} \mathrm{m})$ ), based on aerial photographs taken in 1949 , I 956 and 1963 by Hunting Survey Corporation, Vancouver, B.C. The earliest one does not cover the region of the terminus, and none of them covers the upper reaches of the accumulation area. The data presented in Table I are based on the I 963 map, extended for the upper reaches of the glacier by an approximate topography taken from Sheet I04B, "National Topographic Series" of Canada (scale I : 250 o0o). The coordinate $x$ (at intervals of $\Delta x=600 \mathrm{~m}$ ) was measured along median lines of the two major and several minor ice streams of Berendon Glacier. The widths of each of the individual streams, at the same $x$, were measured roughly along contour lines and added to obtain the function $B_{0}(x)$ for the whole glacier. Since the variation of altitude with $x$ is different in each tributary, the mean altitude $z$ over each interval $\Delta x$ was determined by weighting the altitudes of the tributary strips according to their widths. The variation of the mass balance $a$ with $x$ was then estimated from the known variation with altitude of the mass balances of eight other glaciers along the coast between Washington and Alaska (Meier and Post, I962). Combined with the values of $B_{0}$, the chosen function $a(x)$ gave a negative mean mass balance, as was likely to be true in 1963 . A uniform addition of $+\mathrm{I} 5$ $\mathrm{cm} /$ year at all heights was made to establish the function $a_{0}(x)$ giving a zero mean mass balance as required for the datum state.

An idealized steady-state datum glacier was thus set up which had a length approximately equal to that of the real glacier in 1963 . The bedrock topography is not known and had to be inferred from cross-sections of the valleys in the lower part of the glacier, and estimated in the upper part. The annual discharge volumes $\mathbf{q}_{0}$ and the ice velocities $u_{0}$ in this datum glacier, implied by the assumed mass-balance curve and the assumed cross-sectional areas of the glacier, were reasonable but could not be checked against actual measurements. It is clear that the resulting functions $B_{0}(x), \mathbf{c}_{0}(x), \mathbf{D}_{0}(x)$ for Berendon Glacier are very approximate. When calculating the response of the terminus it is fortunately not necessary that the functions should be known in detail in the upper reaches of the glacier, for the response is the result of an integration down the length of the glacier. But it is important that the value of $\mathbf{c}_{0}(x)$ at the terminus itself $(x=L)$ should be accurately known. For example, the response of the terminus to a long-term change in mean mass balance, $a_{\mathrm{I}}$, is given by

$$
h_{\mathrm{I}}=a_{\mathrm{I}} \int_{0}^{L} B_{0}(x) \mathrm{d} x / \mathbf{c}_{0}(L),
$$

where $h_{\mathrm{I}}$ is the thickening at the terminus. The integral is simply the area of the glacier. An error in $\mathbf{c}_{0}(L)$ thus leads directly to an equal percentage error in the calculated response. We estimated $\mathbf{c}_{0}(L)$ as between $0.5 \times \mathrm{IO}^{4}$ and $\mathrm{r} .0 \times \mathrm{IO}^{4} \mathrm{~m}^{2} /$ year $^{-1}$ with the most likely value as $0.7 \times 10^{4} \mathrm{~m}^{2} /$ year $^{-1}$. If the object had been to compute the response of the terminus, this uncertainty in $\mathbf{c}_{0}(L)$ would have been a serious source of error. There would also have been difficulties in interpreting the theory in a region where the width of the glacier is changing by relatively large amounts. But, in fact, the threat of the glacier to the installations was not at the terminus itself $(x=8790 \mathrm{~m})$ but at a point $800 \mathrm{~m}$ further up-glacier $(x=7990 \mathrm{~m})$; at this position the portal of the mine workings (marked by a cross in Figure $\mathrm{I}$ ) lay $\mathrm{I} 9 \mathrm{~m}$ above the $1_{96} 6_{3}$ ice level. The width in this region is relatively well defined, and, as we verified by computation, the response at this point was comparatively insensitive to the value chosen for $\mathbf{c}_{0}(L)$. The following calculations all refer, not to the terminus, but to this particular place, $x=7990 \mathrm{~m}(x / L=0.9 \mathrm{I})$.

The theory given by Nye ( $\left.9_{6} 63[\mathrm{~b}]\right)$ connects the time variation in the mean mass balance* $a_{1}(t)$ with the time variation in the thickness of the glacier $h_{\mathrm{I}}(t)$ at the particular value of $x$

* The $a_{\mathrm{r}}(t)$ of the theory is not identical with the mean mass balance, but the differences do not matter in this application. 
through the equation

$$
a_{\mathrm{I}}(t)=\lambda_{0} h_{\mathrm{I}}(t)+\lambda_{\mathrm{I}} \dot{h}_{\mathrm{I}}(t)+\lambda_{2} \ddot{h}_{\mathrm{I}}(t)+\ldots,
$$

where the dots denote differentiation with respect to time, and the $\lambda$ 's are numerical coefficients that may be computed for the particular $x$ in question. $h_{\mathrm{I}}(t)$ measures the rise or fall of the upper surface of the glacier relative to the upper surface of the fixed datum glacier. The values of the $\lambda$ 's at $x=7990 \mathrm{~m}$ were computed by machine by the method described by Nye ( $1963[\mathrm{~b}])$ using the known functions $B_{0}(x), \mathbf{c}_{0}(x), \mathbf{D}_{0}(x)$ as input data, with the following results :

$$
\lambda_{0}=0.0025 \text { year }^{-1}, \quad \lambda_{1}=0.12, \quad \lambda_{2}=1.8 \text { year }, \quad \lambda_{3}=5.4 \text { year }^{2} .
$$

The value of $h_{\mathrm{I}}$ in $\mathrm{I}_{9} 63$ at $x=L$ is zero, by definition of the datum glacier. We assume that $h_{\mathrm{r}}$ in $\mathrm{I}_{9} 6_{3}$ is also zero at $x=7990 \mathrm{~m}$, although it is probably slightly negative. The problem is to assess the likelihood that $h_{\mathrm{I}}$ at $x=7990 \mathrm{~m}$ will reach a critical level (taken as $19 \mathrm{~m}$, for then the ice would reach the portal) within a specified time, say 40 years. Our procedure is to assume a polynomial in $t$ for $h_{\mathrm{I}}(t)$ that is (a) consistent with what is known about $h_{\mathrm{I}}$ in 1963 and (b) will make $h_{\mathrm{1}}(t)$ have the critical value $\mathrm{I} 9 \mathrm{~m}$ at a time 40 years later. We then use Equation ( $\mathrm{I}$ ) to compute the corresponding function $a_{\mathrm{I}}(t)$, and assess the likelihood of such a variation in the light of other mass-balance data.

From the maps of 1949 , I956 and 1963 it was determined that the ice thickness in the region under consideration has been diminishing by about $2.4 \mathrm{~m} /$ year. Thus, taking $t=0$ in 1963 , we have

$$
h_{\mathrm{I}}(\mathrm{o})=\mathrm{o}, \quad \dot{h}_{\mathrm{I}}(\mathrm{o})=-2.4 \mathrm{~m} / \text { year, } \quad h_{\mathrm{I}}(40)=19 \mathrm{~m} .
$$

The simplest polynomial function $h_{\mathrm{I}}(t)$ consistent with this information is (curve $\mathrm{L}_{\mathrm{I}}$ in Figure 2)

$$
h_{\mathrm{I}}(t)=p_{\mathrm{I}} t+p_{2} t^{2},
$$

where $p_{1}$ and $p_{2}$ are constants that can be determined. Then

$$
\dot{h}_{\mathrm{I}}(t)=p_{\mathrm{I}}+2 p_{2} t, \quad \ddot{h}_{\mathrm{I}}(t)=2 p_{2},
$$

and all higher derivatives are zero. So, substituting in Equation (I),

$$
a_{\mathrm{I}}(t)=\left(p_{\mathrm{I}} \lambda_{\mathrm{I}}+2 p_{2} \lambda_{2}\right)+\left(p_{\mathrm{I}} \lambda_{0}+2 p_{2} \lambda_{\mathrm{I}}\right) t+p_{2} \lambda_{0} t^{2} .
$$

Using the values of the $\lambda$ 's and the $p$ 's we find

$$
a_{\mathrm{r}}(t)=-0.03+0.0 \mathrm{I} \mathrm{I} t+0.000 \mathrm{I} 8 t^{2},
$$

in units of metres and years. This is an almost linear variation in $a_{\mathrm{I}}$ from the value -0.03 $\mathrm{m} /$ year at $t=0$ to $+0.7 \mathrm{I} \mathrm{m} /$ year at $t=40$ year (curve $\mathrm{B}_{\mathrm{I}}$ in Figure 2 ). The mean mass balance in 1963 is not known, but the value $-3 \mathrm{~cm}$ is not unlikely. The calculation then shows that if the mean mass balance should increase smoothly to about $+70 \mathrm{~cm}$, which is a high but possible value, in the year 2003 , the ice level would continue to drop until r980, regain its original height in 1996 and reach the critical level in 2003 (as postulated).

When the calculation is repeated with the postulate that the ice reaches the critical level in 20 years instead of 40 years, the resulting curves are shown as $\mathrm{L}_{2}$ and $\mathrm{B}_{2}$ in Figure 2 . This case is unlikely for two reasons: ( $\mathrm{I}$ ) a steady increase of mean mass balance to $+\mathrm{I} 20 \mathrm{~cm}$ in 20 years is greater than can reasonably be expected judging from other mass-balance data, and (2) in order for the ice to reverse its trend by 1970 the mean mass balance in I 963 had to be $+30 \mathrm{~cm}$, while in fact it was probably negative at that time.

If, for a third calculation, we introduce the additional restriction that the mean mass balance in ${ }^{9} 963$ was zero, we must bring in extra terms in $t^{3}$ in the polynomials for $h_{\mathrm{r}}(t)$ and $a_{\mathrm{I}}(t)$. Thus the conditions

$$
h_{\mathrm{I}}(\mathrm{o})=\mathrm{o}, \quad \dot{h}_{\mathrm{I}}(\mathrm{o})=-2.4 \mathrm{~m} / \text { year }^{-1}, \quad h_{1}(20)=\mathrm{I} 9 \mathrm{~m}, \quad a_{\mathrm{I}}(\mathrm{o})=\mathrm{o}
$$

may be shown to give

and hence

$$
\begin{gathered}
a_{\mathrm{I}}(t)=0.08 \mathrm{o} t+0.0029 t^{2}+0.000020 t^{3} \\
a_{\mathrm{I}}(20)=2.9 \mathrm{~m} / \text { year }^{-1} .
\end{gathered}
$$


The mean mass balance in this case has to rise steadily from zero to about $+290 \mathrm{~cm}$ in order for the ice to reverse its trend and reach the tunnel in 20 years.

Thus it may be concluded that, even assuming a rather drastic deterioration in the climate in the future and a concomitant increase of the mean mass balance, the ice will not reach the tunnel portal within the next 20 years.

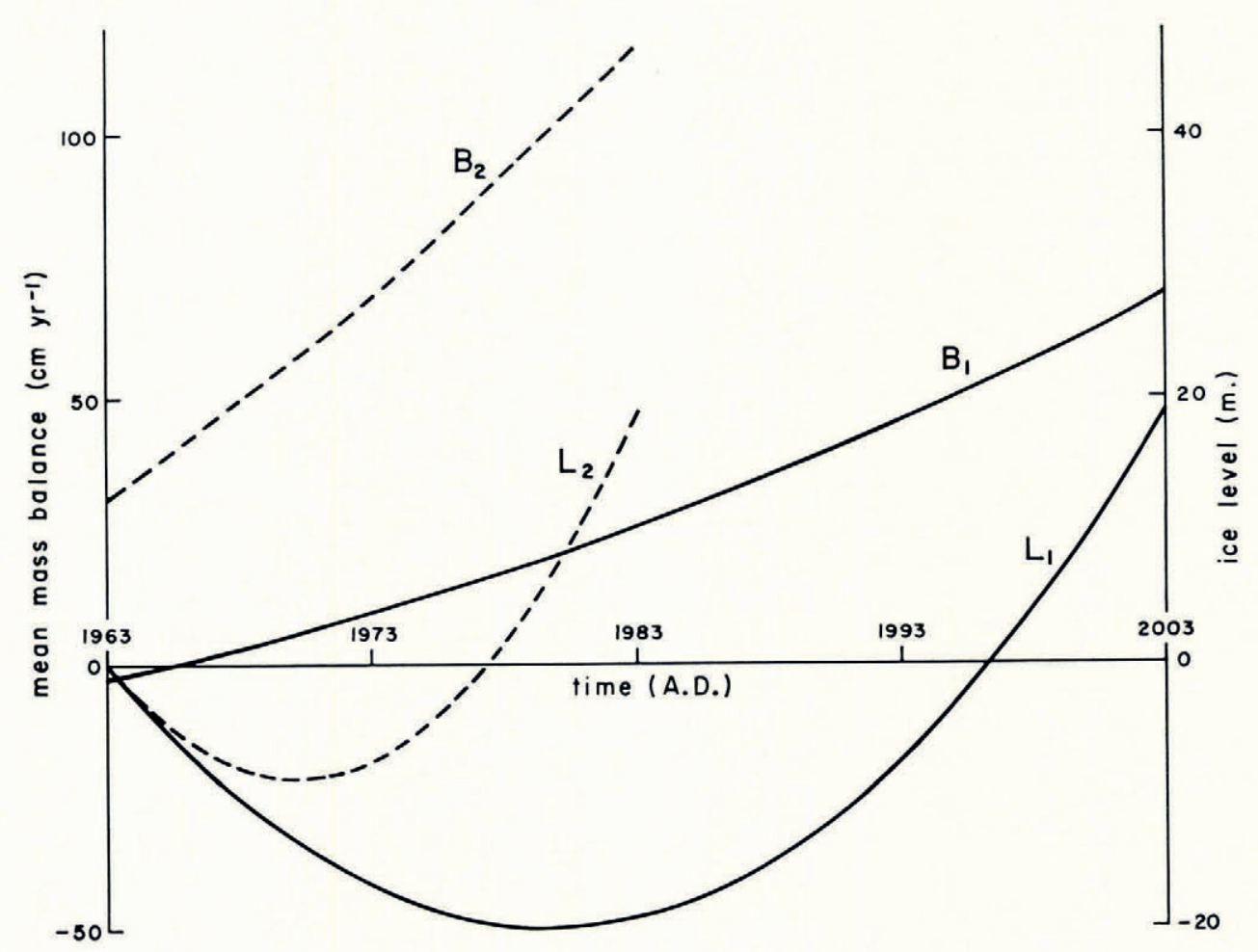

Fig. 2. Curves $\mathbf{L}_{1}$ and $\mathrm{L}_{2}$ : postulated change in ice level near tunnel portal. Ice reaches portal in $4^{o}$ and 20 years respectively. Curves $\mathrm{B}_{1}$ and $\mathrm{B}_{2}$ : calculated mean mass balances corresponding to curves $\mathrm{L}_{1}$ and $\mathrm{L}_{2}$

\section{AcKNOWLEDGEMENTs}

This work was undertaken at the suggestion of Dr A. A. Brant, and supported by Newmont Exploration Ltd. and the Granduc Operating Company. We should like to thank Professors M. F. Meier and W. H. Mathews for considerable help in assembling and evaluating the observations we have used in our computations. The computations of the $\lambda$ coefficients were done on the IBM 7094 machine at the University of Washington, and the computations of the $e(n)$ and of the frequency response were done on the IBM System 360 at the Computing Facility, University of California, Los Angeles. One of us (J.F.N.) would like to thank the Department of Geology and the Institute of Geophysics and Planetary Physics, University of California, Los Angeles, for their hospitality during the writing of this paper. Publication costs were borne by the National Science Foundation, grant GP-297I. 


\section{REFERENCES}

Meier, M. F., and Post, A. S. I962. Recent variations in mass net budgets of glaciers in western North America. Union Géodésique et Géophysique Internationale. Association Internationale d'Hydrologie Scientifique. Commission des Neiges et Glaces. Colloque d'Obergurgl, $10-9-18-9$ I962, p. $63-77$.

Nye, J. F. 1960. The response of glaciers and ice-sheets to seasonal and climatic changes. Proceedings of the Royal Society, Ser. A, Vol. 256, No. 1287, p. 559-84.

Nye, J. F. $1963[\mathrm{a}]$. On the theory of the advance and retreat of glaciers. Geophysical Journal of the Royal Astronomical Society, Vol. 7 , No. 4 , p. $43 \mathrm{I}-56$.

Nye, J. F. $1963[\mathrm{~b}]$. The response of a glacier to changes in the rate of nourishment and wastage. Proceedings of the Royal Society, Ser. A, Vol. 275, No. 1360, p. 87-112.

Nye, J. F. 1965[a]. The frequency response of glaciers. Journal of Glaciology, Vol. 5, No. 41, p. $5^{67}-87$.

Nye, J. F. I $965[\mathrm{~b}]$. A numerical method of inferring the budget history of a glacier from its advance and retreat. fournal of Glaciology, Vol. 5, No. 41, p. 589-607.

\section{APPENDIX}

\section{Further Computations}

We have also calculated as a matter of interest, and for comparison with other glaciers, the influence coefficients $e(n)$ and $g(n)$ (Nye I965[b]) and the frequency response (Nye I965[a]).

The influence coefficients $e(n)$ give the response to a unit impulse of $a_{\mathrm{I}}(t)$. The result is a flood wave on the glacier which is shown in Figures $3 a$ and b. In Figure $3 a$ one sees the growth and decay of the wave at selected positions on the glacier, while in Figure $3 \mathrm{~b}$ one sees the path of the wave in an $x: t$ diagram. Note that the wave is not a moving bulge on the glacier surface, for at any given time $h_{\mathrm{I}}$ increases steadily with $x$, with no maximum.

We have not used the influence coefficients explicitly in assessing the future behaviour of the glacier in the neighbourhood of the tunnel portal for the following reason. The future behaviour is the sum of (I) the response to past mean mass balances and (2) the response to future mean mass balances. The past mean mass balances of the glacier have not been measured, and in the present state of knowledge it is impossible to infer them from measurements on other glaciers. (We refer here to the time variation of the mean mass balance over the glacier surface, rather than the $x$ variation of the mass balance. It is possible to infer the latter from other glaciers, but not the former.) Nevertheless the relevant information on past mean mass balances is actually present in the glacier in the form of a distribution of $h_{1}(x)$, and if $h_{\mathrm{r}}(x)$ were known (which it is not), the future response to past mean mass balances could, in

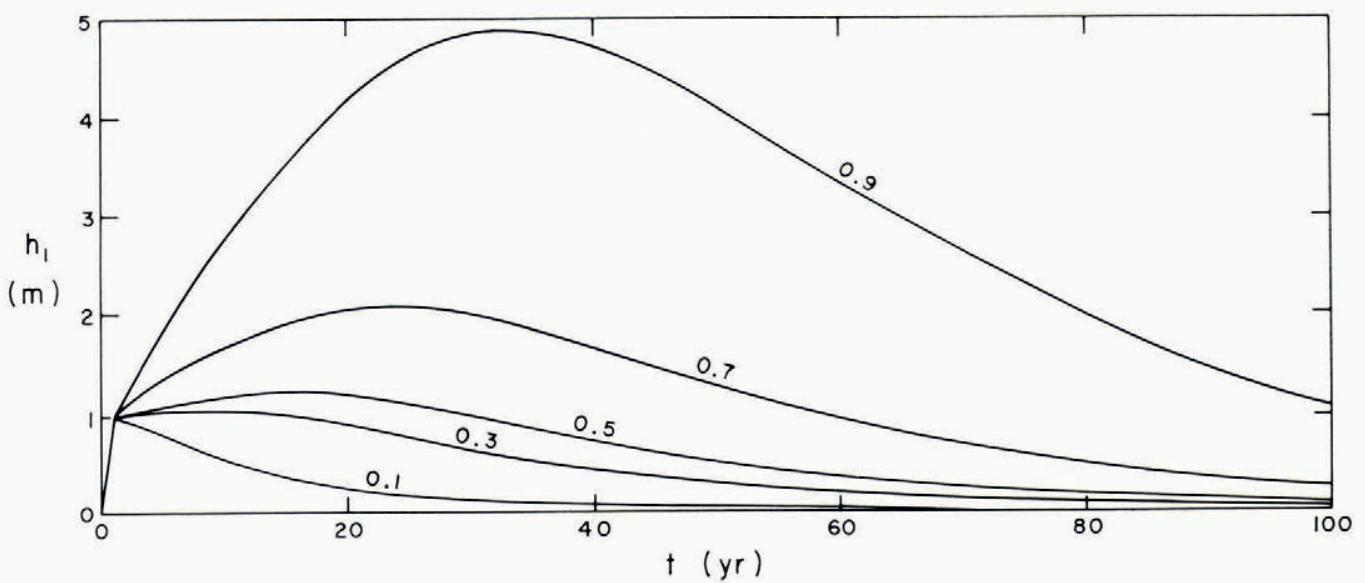

Fig. 3a. Computed response of Berendon Glacier to a unit impulse. $h_{\mathrm{t}}$ is the increase of thickness in metres. The mean balance was taken as $+I m /$ year from $t=o$ to $t=I$ year and zero at other times. Numbers against the curves refer to the values of $x / L$. For points higher up glacier than $x / L \approx 0.15$ the initial increment in thickness begins to decay at once. For points lower down the glacier a flood wave builds up and then decays 


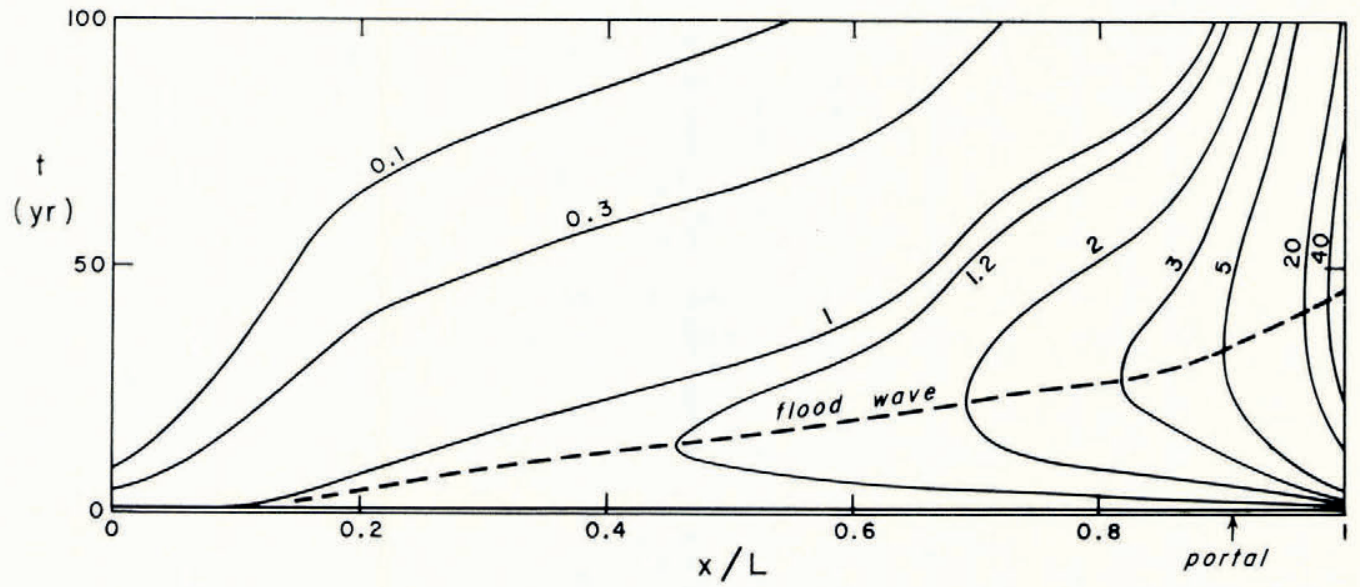

Fig. $3 b$. The same as Figure $3 a$ but showing lines of equal $h_{1}$ on an $x: t$ diagram. The broken line shows the progress of the flood wave. Numbers against curves are the values of $h_{1}$ in meters

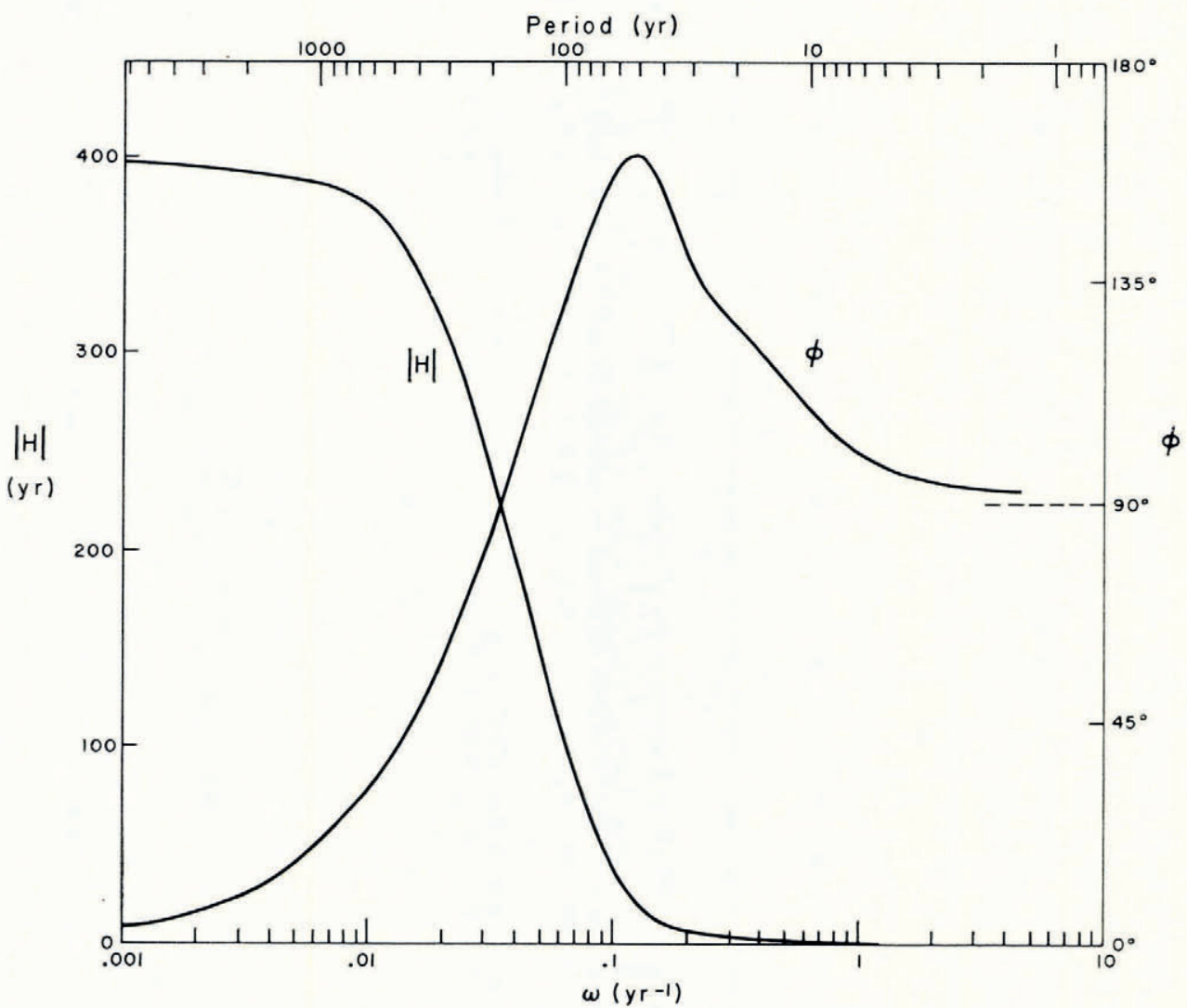

Fig. 4. Computed frequency response at $x=7990 \mathrm{~m}(x / L=0.9 \mathrm{I})$ to a periodic variation in mean mass balance of unit amplitude. The amplitude $|H|$ and phase lag $\phi$ of the response are plotted against the angular frequency $\omega$ 
principle, be worked out completely. This response to past mass balances would of course include the present retreat rate as one of its features. Component (2) of the future behaviour depends on the future climate. If limits are set to the possible future mass balances, limits may correspondingly be fixed for the glacier response, and the most convenient way of doing this is by use of the $e(n)$ coefficients. However, in the present application the only information we have on (I) is the present retreat rate, and it is therefore better to use the polynomial method, with the $\lambda$ coefficients, that we have described.

The influence coefficients $g(n)$ follow a pattern similar to that previously found for South Cascade Glacier and Storglaciären.

The frequency response at $x=7990 \mathrm{~m}$ is shown in Figure 4. The curves are similar to those in Nye ( $1965[\mathrm{a}])$. The curve of phase lag against frequency shows a single maximum at a period of $5^{2}$ years. 